\title{
Overexpression of platelet-derived growth factor-B increases the growth, invasion, and angiogenesis of gastric carcinoma cells through protein kinase $B$
}

\author{
Y. GUO ${ }^{1,2}$, J. YIN ${ }^{3}$, Z. WANG ${ }^{2, *}$, L. ZHA ${ }^{2}$ \\ ${ }^{1}$ Department of General Surgery, Chongqing Traditional Chinese Medicine Hospital, Chongqing, China; ${ }^{2}$ Department of Gastrointestinal \\ Surgery, ${ }^{3}$ Department of Gastroenterology, First Affiliated Hospital of Chongqing Medical University, Chongqing, China
}

*Correspondence: wangziwei571@hotmail.com

Received November 18, 2012 / Accepted March 21, 2013

\begin{abstract}
Platelet-derived growth factor-B (PDGF-B) promotes tumor metastasis by inducing tumor cell growth, invasion, and angiogenesis in several cancers. However, the roles of PDGF-B in gastric carcinoma are largely unknown. We established two gastric carcinoma cell lines, SGC7901 and BGC823, to stably overexpress PDGF-B by lentiviral vectors, and determined their growth, invasion and angiogenesis. Overexpression of PDGF-B significantly enhanced the cell proliferation, invasion and angiogenesis of both SGC7901 and BGC823 cells, accompanied with increased activation of AKT, which is a downstream target of PDGF signaling pathway. Consequently, an AKT kinase inhibitor abolished the PDGF-B overexpression-mediated up-regulation of growth, invasion and angiogenesis. These results indicate that PDGF-B signaling may promote the metastasis of gastric carcinoma through AKT signaling. Targeting the PDGF-B pathway may be an alternative strategy for the development of therapies for gastric cancers.
\end{abstract}

Key words: platelet-derived growth factor B (PDGF-B), gastric carcinoma, cell growth, invasion, angiogenesis, AKT

Growth factors, including platelet-derived growth factor (PDGF), play key roles in the multiple processes of tumorigenesis [1,2]. Inhibiting growth factor signaling pathways is the major effort for the current era of "targeted therapies", with numerous inhibitors in pre-clinical and clinical trials for cancer therapy $[3,4,5]$.

Members of the PDGF family are directly implicated in many malignancies $[1,5,6]$. The PDGF family consists of five isoforms, PDGF-A (AA), PDGF-B (AB and $\mathrm{BB}$ ), PDGF-C (CC), and PDGF-D (DD) [7]. PDGFs regulate diverse cellular functions through two PDGF receptors (PDGFRs), PDGFR- $\alpha$ and PDGFR- $\beta$ [8]. PDGFR- $\alpha$ binds all isoforms of PDGF except PDGF-D, whereas PDGFR- $\beta$ binds PDGF- $B$ and PDGF-D $[8,9]$. PDGFs promote tumorigenesis by directly stimulating tumor cell growth [10], angiogenesis and lymphangiogenesis [11,12], inducing Epithelial-mesenchymal transition (EMT) [13], and recruiting pericytes [14]. In addition, PDGFs activate AKT1 and AKT2, which play key roles in multiple cellular processes, such as glucose metabolism, apoptosis, cell proliferation, transcription, and cell migration [15]. Thus, the PDGF signaling pathway is a significant target for the treatment of tumors.
Recent studies showed that PDGF-B is expressed at high levels in gastric carcinoma $[12,16]$, suggesting that the PDGF$\mathrm{B}$ signaling pathway may be important in the progression of gastric carcinoma. Therefore, we established PDGF-B stably overexpressed SGC7901 and BGC823 gastric carcinoma cells. We found that overexpression of PDGF-B enhanced the cell growth, invasion, and angiogenesis of these cells.

\section{Materials and methods}

AKT inhibitor. AKT inhibitor VIII, Isozyme-Selective, AKTi-1/2 (Santa cruz Biotechnology. Inc. USA) was used in this study at a concentration of $0.1 \mu \mathrm{g} / \mathrm{ml}$.

Cell culture. SGC7901 and BGC823 human gastric carcinoma cell lines and human umbilical vein endothelial cells (HUVECs) were provided by the Cell Bank of Chinese Academy of Sciences, Shanghai, China. Cells were cultured in RPM1640 media supplemented with 10\% fetal bovine serum (FBS).

Lentiviral vector constructs and preparation. A lentiviraldelivered PDGF-B vector was constructed and prepared by Chongqing Western Technology Inc (Chongqing, China) as 
described by Lois et al. [17] and Xia et al. [18]. Briefly, primers were designed according to the PDGF-B sequence (Genbank Accession Number NM_002608.2). The primer sequences are: PDGF-B-F, 5' - ATGAATCGCTGCTGGGCGCTC-3'; PDGFB-R, 5'-CTAGGCTCCAAGGGTCTCCTTC-3'. Target gene was obtained by Polymerase Chain Reaction (PCR) and was inserted into the pUC57 vector. Then, both pLenO-DCE and pUC57-PDGF-B were enzyme digested by EcoR I and Not I respectively. After ligation, the pLenO-DCE-PDGF-B vector was constructed. After sequencing, pLenO-DCE-PDGF-B vector was transfected into $293 \mathrm{~T}$ cells and lentiviral-delivered PDGF-B vector was prepared.

Cell transfection. Briefly, $1 \times 10^{5}$ SGC7901 and BGC 823 cells were seeded in each well of a 6 -well plate in $500 \mu$ l of complete media at $37^{\circ} \mathrm{C}$ in a $5 \% \mathrm{CO}_{2}$ incubator for $24 \mathrm{~h}$, and then transduced by lentiviral vectors at a multiplicity of infection of 10:1 [19]. Transduction was carried out in the presence of Polybrene $(8 \mu \mathrm{g} / \mathrm{ml})$. After washing three times with PBS, $1 \mathrm{ml}$ of RPMI1640 was added in each well. Cells were seeded at $37^{\circ} \mathrm{C}$ in a $5 \% \mathrm{CO}_{2}$ incubator for $48 \mathrm{~h}$. Fluorescence microscopy was used to observe the transduction. G418 (400 $\mu \mathrm{g} / \mathrm{ml})$ was used for screening. Transduced cells were passaged and seeded for further experiments.

MTT assay. Cells $\left(5 \times 10^{3}\right)$ were seeded in a 96-well plate (BD Biosciences, USA) and harvested for the MTT assay at indicated times from days 1-6. Cell samples were incubated with $20 \mu \mathrm{l}$ of MTT ( $5 \mathrm{mg} / \mathrm{mL}$; Sigma, USA) for $6 \mathrm{~h}$. Following the removal of the MTT solution, formazan crystals were dissolved in $150 \mu \mathrm{l}$ of dimethyl sulfoxide (DMSO, Sigma, USA). The absorption of the solution was measured at 570 $\mathrm{nm}[20]$.

Transwell invasion assay. Invasion chambers coated with Matrigel were purchased from BD Biosciences. Assays were conducted as described by Sarah E et al. [21]. Briefly, cells $\left(1 \times 10^{5}\right)$ were added to the top chambers $(300 \mu \mathrm{l}$ RPMI1640) of 24 -well transwell plates (BD Biosciences; $8 \mu \mathrm{m}$ pore size). After $24 \mathrm{~h}$, the top (non-migrated) cells were removed, and the bottom (migrated) cells were fixed with $70 \%$ methanol andstained with trypan blue to visualize nuclei. The number of migrating cells in five fields was counted under $100 \times$ magnification, and the mean for each chamber was determined with ImageJ (version 1.38, National Institutes of Health). Experiments were repeated for a minimum of three times.

Matrigel assay. The bottoms of cell chambers were coated with a 300 microliter $(\mu \mathrm{l})$ mixture of Matrigel $(50 \mathrm{mg} / \mathrm{L})$ without anti-serum (ratio:1:2), and was preheated at $37^{\circ} \mathrm{C}$ for $30 \mathrm{~min}$. HUVECs $\left(5 \times 10^{4}\right)$ were added to the top chambers (300 $\mu \mathrm{l}$ RPMI1640) of 24 -well transwell plates. $6 \times 100 \mu \mathrm{l} \mathrm{su}$ pernatant from PDGF-B overexpressed SGC7901 and BGC823 gastric carcinoma cells and $6 \times 100 \mu \mathrm{l}$ supernatant from normal SGC7901 and BGC823 gastric carcinoma cells were added in each well with RPMI1640 (ratio:1:2). After $24 \mathrm{~h}$, the number of neovessels (number of nodes $\times$ the number of branches/perimage) was calculated under $400 \times$ magnification according to Chigurupaliet al [22].
Western blot analysis. Cells were lysed on ice in RIPA buffer $(50 \mathrm{mM}$ Tris-HCl, $150 \mathrm{mM} \mathrm{NaCl}, 1 \% \mathrm{NP}-40,0.1 \%$ SDS, $0.5 \%$ sodium deoxycholate, $2 \mathrm{mM}$ sodium fluoride, $2 \mathrm{mM} \mathrm{Na}_{3} \mathrm{VO}_{2}, 1 \mathrm{mM}$ EDTA, and $1 \mathrm{mM}$ EGTA). Total protein extracts were analyzed by western blotting, as described previously [23]. Proteins $(20 \mu \mathrm{g})$ were separated by SDS-PAGE gels (Invitrogen) and transferred to PVDF membranes. The membranes were blotted for $1 \mathrm{~h}$ with 5\% milk. Membranes were incubated with primary antibodies (1:500 dilution) against AKT-1or p-AKT-S473 (Santa Cruz Biotechnology, Inc. USA) at $4^{\circ} \mathrm{C}$ for overnight. After incubation with horseradish peroxidase-conjugated secondary antibody (1:1000 dilution) for $3 \mathrm{~h}$ at $37^{\circ} \mathrm{C}$, signals were detected by ECL chemiluminescence for $5 \mathrm{~min}$. The films were analyzed by densitometry with image software.

Statistics analysis. Data were expressed as mean \pm SE and statistically evaluated by one-way ANOVA followed by a Newman-Keuls test. $\mathrm{P}<0.05$ was considered statistically significant.

\section{Results}

PDGF-B overexpression increased the activity of AKT-1 in SGC7901 and BGC823 gastric carcinoma cells. To check the overexpression of PDGF-B in our stably transfected cells and see if overexpression of PDGF-B leads to increased activation of AKT, we checked the pAKT-S473, a marker for the activity of AKT pathway, in our SGC7901 and BGC823 gastric carcinoma cells, which has been transduced with lentiviral constructs to overexpress PDGF-B. As illustrated in Figure 1, our stably transduced cells overexpressed PDGF-B, and PDGF-B overexpression significantly increased both the protein levels of AKT-1 and the phosphorylation of AKT at phosphorylation site S-473 ( $\mathrm{p}<0.05)$ (Fig. 1), supporting the previous finding that ATK is a downstream signaling target of the PDGF pathway [24,25].

Overexpression of PDGF-B increased the cell growth of SGC7901 and BGC823 gastric carcinoma cells. We determined the cell growth of SGC7901, PDGF-B overexpression SGC7901 (SGC7901/PDGF-B), BGC823 and PDGF-B overexpression BGC823 (BGC823/PDGF-B) cells. We also determined the cell growth of SGC7901, PDGF-B overexpression SGC7901 (SGC7901/PDGF-B), BGC823 and PDGF-B overexpression BGC823 (BGC823/PDGF-B) cells after being treated with an AKT inhibitor. Compared with SGC7901 and BGC823 cells, the cell growth of SGC7901/PDGF-B and BGC823/PDGF-B cells increased significantly ( $<<0.05)$ (Fig. 2). In consistence with the activation of AKT by PDGF-B (Fig. 1), treatment with an AKT inhibitor significantly reduced the cell growth of SGC7901/PDGF-B and BGC823/PDGF-B cells ( $\mathrm{p}<0.05$ ), but treatment with an $\mathrm{AKT}$ inhibitor did not reduce the cell growth of SGC7901 and BGC823 ( $\mathrm{p}>0.05$ ). Significant differences were not observed between SGC7901/PDGF-B and BGC823/PDGF$B$ cells treated with an AKT inhibitor and normal SGC7901 and BGC823 cells ( $p>0.05)$ (Fig. 2). 
$\mathbf{N}$

SGC7901 BGC823 SGC7901 BGC823

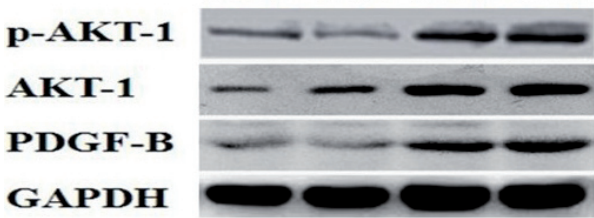

$62 \mathrm{kD}$

60kD

25kD

$36 \mathbf{k D}$

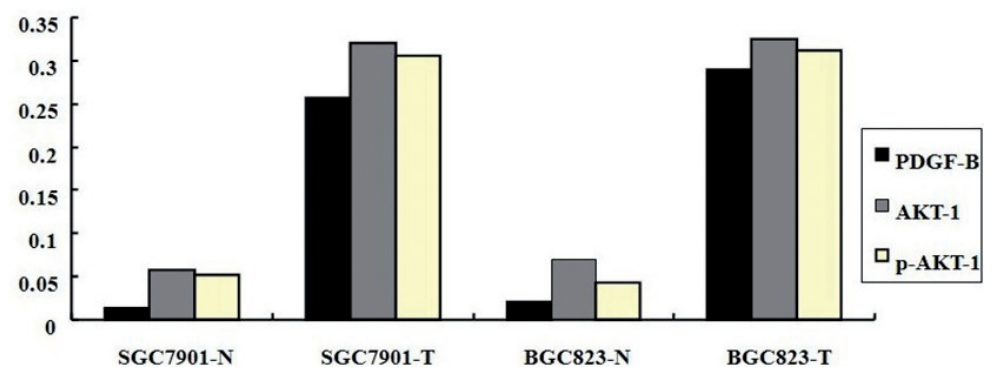

Figure 1. Overexpression of PDGF-B activated AKT-1 in SGC7901 and BGC823 cells.

Western blot analysis of the expression of PDGF-B, AKT-1 and p-AKT-1 in SGC7901 and BGC823 cells before and after transduction with PDGF-B lentiviral vectors. GAPDH was used as a protein loading control. As shown, expression of PDGF-B, AKT-1 and p-AKT-1 were much higher in transduced SGC7901 and BGC823 cells than in normal SGC7901 and BGC823 cells $(\mathrm{p}<0.05) . \mathrm{N}=$ normal cells; $\mathrm{T}=$ cells after transduction.
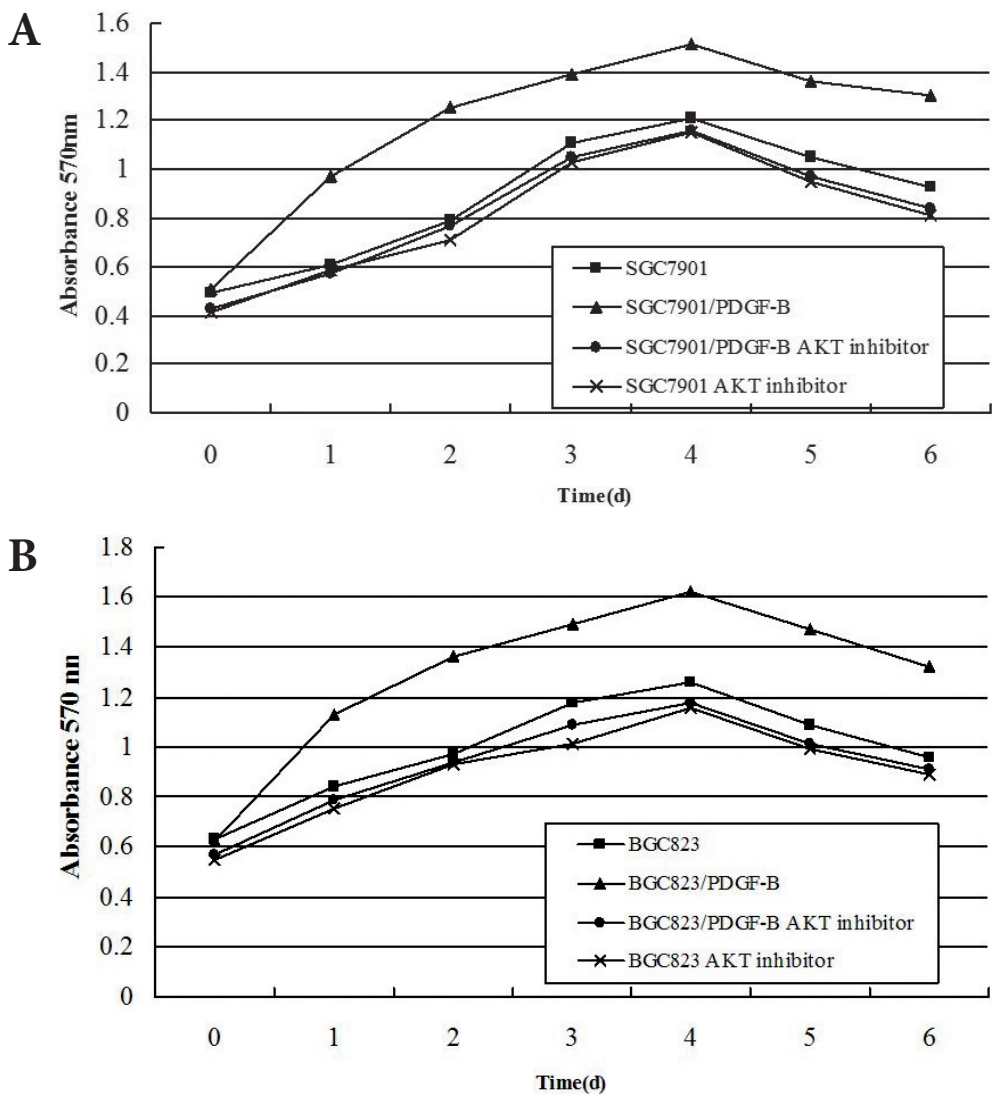

Figure 2.Cell growth of SGC7901/PDGF-B, SGC7901, BGC823/PDGF-B and BGC823 cells, and the effect of an AKT inhibitor on the cell growth of SGC7901/PDGF-B, SGC7901, BGC823/PDGF-B and BGC823 cells.

(A) The growth of SGC7901/PDGF-B cells was more rapid than SGC7901 cells ( $p<0.05)$. The growth of SGC7901/PDGF-B cells was inhibited significantly after treating with an AKT inhibitor ( $<<0.05)$, but the growth of SGC7901 cells was not inhibited significantly after treating with an AKT inhibitor ( $>0.05)$.

(B) The growth of BGC823/PDGF-B cells was more rapid than BGC823 cells $(p<0.05)$. The growth of BGC823/PDGF-B cells was inhibited significantly after treating with an AKT inhibitor $(p<0.05)$, but the growth of BGC823 cells was not inhibited significantly after treating with an AKT inhibitor ( $>0.05)$. 
Overexpression of PDGF-B increased the invasion of SGC7901 and BGC823 gastric carcinoma cells. Transwell analysis showed that the number of SGC7901/PDGF-B cells $(65.4 \pm 2.4)$ passing through the matrigel was markedly higher than that of SGC7901 cells $(21.6 \pm 1.6)(\mathrm{p}<0.05)$.
Similarly, the number of BGC823/PDGF-B cells $(70.2 \pm 3.2)$ passing through the matrigel was markedly higher than the number of BGC823 cells $(30.2 \pm 2.2)(\mathrm{p}<0.05)$ (Figure $3)$. After treating with an $A K T$ inhibitor, the number of SGC7901/PDGF-B cells (18.2 \pm 1.4$)$ and BGC823/PDGF-B

$\mathbf{A}$

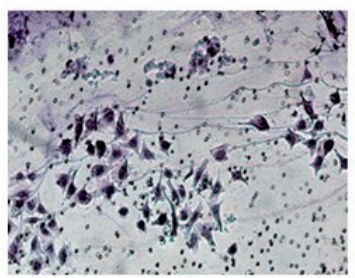

SGC7901/PDGF-B

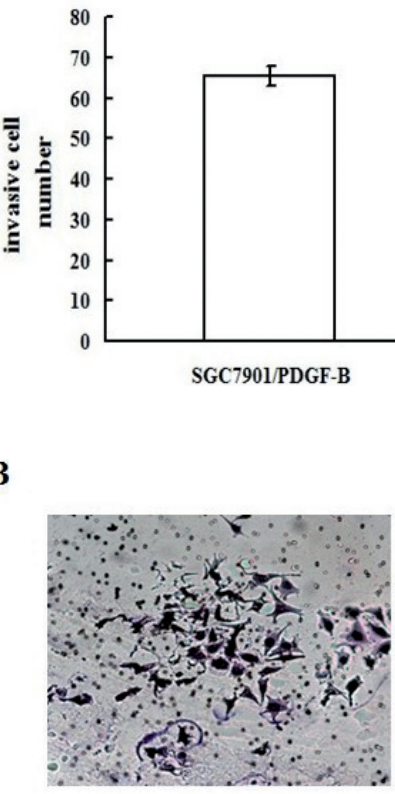

BGC823/PDGF-B

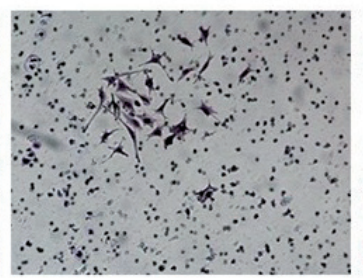

SGC7901

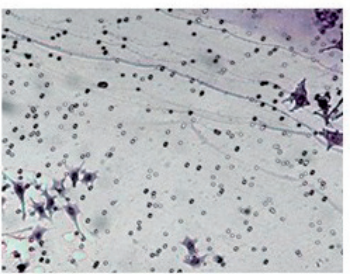

SGC7901/PDGF-B AKT inhibitor

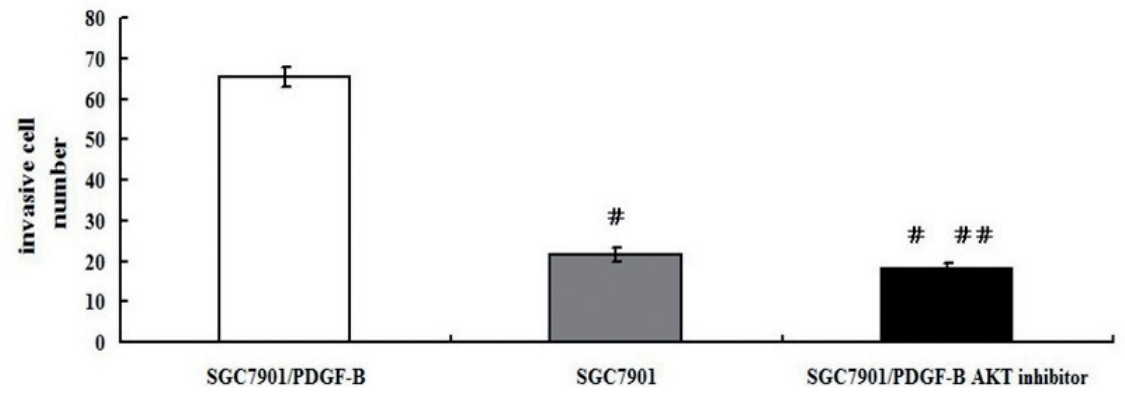

B

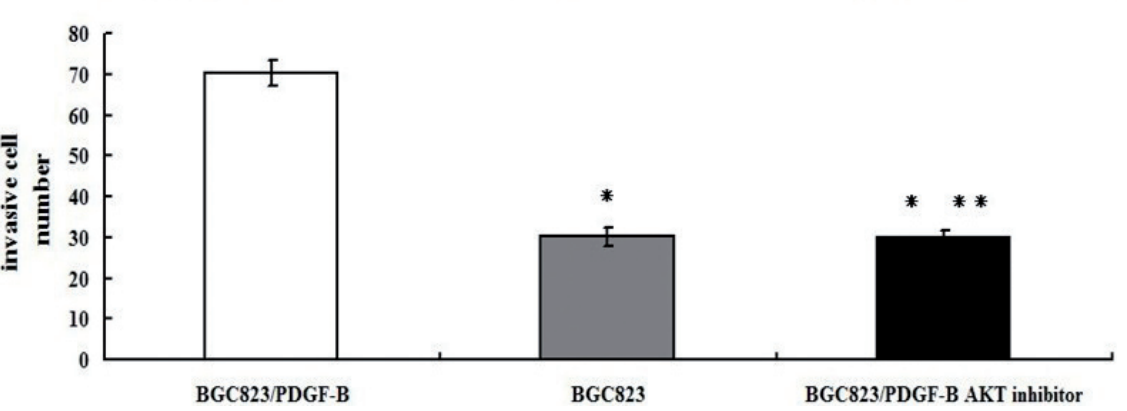

Figure 3.Invasion of SGC7901/PDGF-B, SGC7901, BGC823/PDGF-B and BGC823 cells and the effect of an AKT inhibitor on the invasion of SGC7901/ PDGF-B and BGC823/PDGF-B cells.

(A) Trypan blue staining showed that the SGC7901/PDGF-B and SGC7901 cells passed through thematrigel (100×). ${ }^{\# p<0.05 ~ c o m p a r e d ~ w i t h ~ S G C 7901 / ~}$ PDGF-B cells, ${ }^{\# \#}$ p $>0.05$ compared with SGC7901 cells.

(B) Trypan blue staining showed that the BGC823/PDGF-B and BGC823 cells passed through thematrigel (100 $\times)$. ${ }^{*}<0.05$ compared with BGC823/ PDGF-B, ${ }^{* *} \mathrm{p}>0.05$ compared with BGC823. 
cells $(29.8 \pm 1.8)$ passing through the matrigel were significantly decreased than those of SGC7901/PDGF-B and BGC823/PDGF-B cells $(\mathrm{p}<0.05)$ (Figure 3$)$. Without cell cycle inhibition, the cells seen on the bottom of the filter are the combined result of migration and proliferation. But the cells were detected after one day's seeding, so the influence of proliferation were negligible.
Overexpression of PDGF-B enhanced SGC7901 and BGC823 gastric carcinoma cell angiogenesis. To test the biological significance of PDGF-B in angiogenesis, HUVECs were seeded on matrigelwithout anti-serum and stimulated for $24 \mathrm{~h}$ with conditioned medium from the supernatant of SGC7901/PDGF-B, SGC7901, BGC823/PDGF-B, BGC823, AKT inhibitor added PDGF-B overexpression SGC7901

$\mathbf{A}$

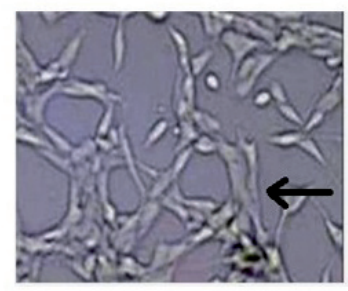

SGC7901/PDGF-B

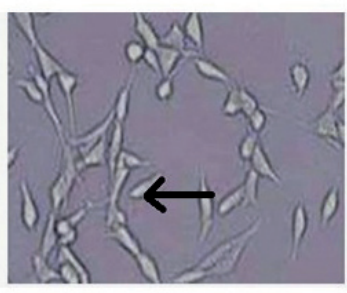

SGC7901

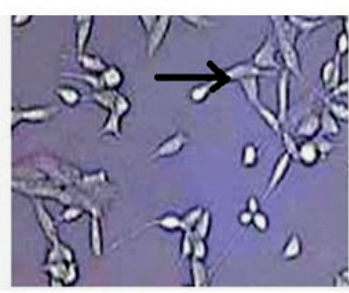

SGC7901/PDGF-B AKT inhibitor

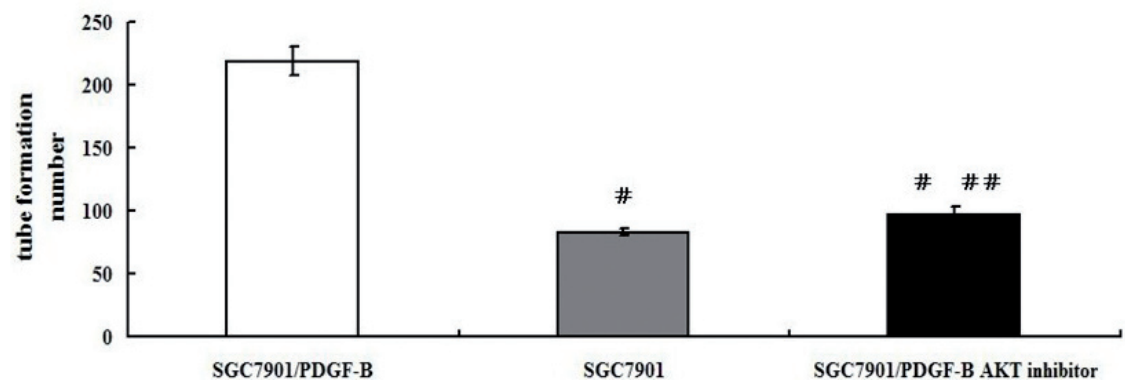

B

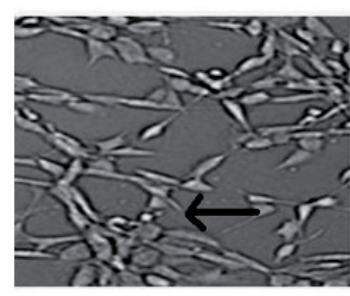

BGC823/PDGF-B

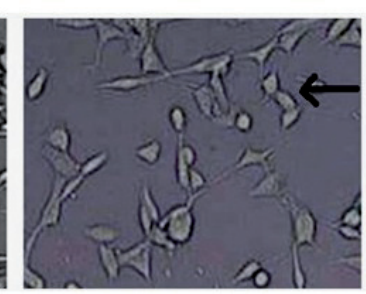

BGC823

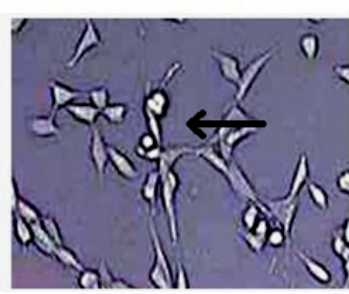

BGC823/PDGF-B AKT inhibitor

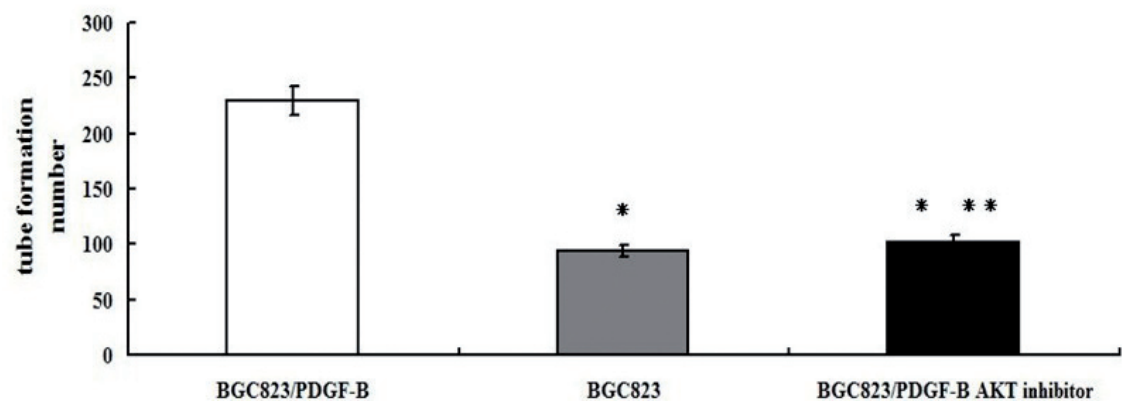

Figure 4. Angiogenesis of SGC7901/PDGF-B, SGC7901, BGC823/PDGF-B and BGC823 cells, and the effect of an AKT inhibitor on the angiogenesis of SGC7901/PDGF-B and BGC823/PDGF-B cells.

(A) HUVEC tube formation $(400 \times) .{ }^{\#} p<0.05$ compared with SGC7901/PDGF-B cells, ${ }^{\# *} p>0.05$ compared with SGC7901 cells.

(B) HUVEC tube formation $(400 \times)$. $p<0.05$ compared with BGC823/PDGF-B, ${ }^{* *} p>0.05$ compared with BGC823. 
(SGC7901/PDGF-B AKT inhibitor) and AKT inhibitor added PDGF-B overexpression BGC823 (BGC823/PDGF-B AKT inhibitor) cells. Then endothelial cell tube formation was assessed. As shown in Figure 4, numerous endothelial tubes were formed after treatment with the different supernatants. However, tube formation was significantly increased when HUVECs were treated with SGC7901/PDGF-B supernatant $(219 \pm 11)$ compared to SGC7901 supernatant $(83 \pm 3)(\mathrm{p}<0.05)$. Moreover, tube formation was significantly increased when HUVECs were treated with BGC823/PDGF-B supernatant $(229 \pm 13)$ when compared with BGC823 supernatant $(94 \pm 5)$ $(\mathrm{p}<0.05)$. In contrast, tube formation was significantly reduced when HUVECs were treated with SGC7901/PDGF-B AKT inhibitor supernatant $(97 \pm 6)$, compared to that treated with SGC7901/PDGF-B supernatant $(\mathrm{p}<0.05)$. Similarly, tube formation was significantly decreased when treated with BGC823/PDGF-B AKT inhibitor supernatant (102 \pm 6$)$, as compared to HUVECs treated with BGC823/PDGF-B supernatant $(\mathrm{p}<0.05)$. These results demonstrated that PDGF-B overexpression increased the angiogenesis of SGC7901 and BGC823 cells, and was abolished when these cells were treated with an AKT inhibitor.

\section{Discussion}

PDGF-B is highly expressed in many types of human cancers, including colorectal cancer [26], gastric cancer [16], liver cancer [27] and thyroid cancer [28], suggesting that PDGF-B may play an important role in the progression, development, invasion and angiogenesis of cancers. Recently, Kodamaet al. [12] and Suzukiet al. [16] reported that PDGF$\mathrm{B}$ was overexpressed in gastric carcinoma, but the functions of PDGF-B in gastric carcinoma remained to be determined. To investigate the role of the PDGF-B signaling pathway in gastric carcinoma, we examined the alteration of cell growth, invasion and angiogenesis of gastric carcinoma cells after overexpressing PDGF-B.

We up-regulated the expression of PDGF-B by transfection of SGC7901 and BGC823 gastric carcinoma cells with PDGF-B constructs. Our data demonstrated that PDGF-B overexpression resulted in a promotion of cell growth, invasion and angiogenesis of SGC7901 and BGC823 cells. These findings indicate that PDGF-B plays an important role in tumor progression. Since tumor progression inhibition is the prerequisite for efficient tumor therapy $[29,30]$, PDGF-B might be a promising target for tumor therapy. Our data indicate that activation of the PI3K-AKT pathway may be one of the underlying mechanisms by which PDGF-B signaling up-regulates the cell growth, invasion and angiogenesis of gastric carcinoma cells.

PI3K-AKT/PKB signaling, a prominent cancer cell growthpromoting pathway [31], can be activated by many types of growth factors to promote cell growth, migration and invasion of tumor cells $[32,33,34]$. Although many studies have demonstrated the role of PDGF-B in gastric carcinoma pro- gression $[12,16]$,we sought to investigate whether the effects of PDGF-B up-regulation on gastric carcinoma was mediated through activation of AKT/PKB signaling. We found PDGF-B overexpression increased the activity of AKT in SGC7901 and BGC823 gastric carcinoma cells, and treatment with an AKT inhibitor reduced gastric carcinoma cell growth, invasion and angiogenesis. Thus, we propose that PDGF-B up-regulation increases gastric carcinoma progression, at least partially, through the activation of AKT/PKB signaling. Further studies are needed to determine themolecular mechanism(s) by which PDGF-B regulates AKT/PKB signaling.

In summary, we determined that PDGF-B promoted the cell growth, invasion, and angiogenesis of gastric carcinoma cells through AKT/PKB signaling, suggesting that PDGF-B plays an important role in the tumor progression and development of gastric carcinoma. Targeting the PDGF-B signaling pathway may be a reasonable approach in treating gastric carcinoma.

Acknowledgments: This work was partly funded by grants from the Department of Gastrointestinal Surgery, First Affiliated Hospital of Chongqing Medical University.

\section{References}

[1] LIU KW, HU B, CHENG SY. Platelet-derived growth factor signaling in human malignancies. Clin J Cancer 2011; 30: 581-584.

[2] CAO Y, CAO R, HEDLUND EM. R Regulation of tumor angiogenesis and metastasis by FGF and PDGF signaling pathways. J Mol Med 2008; 87: 785-789. http: //dx.doi. org/10.1007/s00109-008-0337-z

[3] SAWYERS C. Targeted cancer therapy. Nature 2004; 423: 294-297. http: //dx.doi.org/10.1038/nature03095

[4] GREEN MR. Targeting Targeted Therapy. The new england journal of medicine 2004; 350: 2191-2193. http: //dx.doi. org/10.1056/NEJMe048101

[5] OSTMAN A, HELDIN CK. PDGF Receptors as Targets in Tumor Treatment. Advances in Cancer Research 2007; 97: 247-274. http: //dx.doi.org/10.1016/S0065-230X(06)97011-0

[6] PIETRAS K, SJOBLOM T, RUBIN K, HELDIN CK, ÖSTMAN A. PDGF receptors as cancer drug targets. Cancer Cell 2003; 3: 439-443. http: //dx.doi.org/10.1016/S1535-6108(03)00089$\underline{8}$

[7] HELDIN CH, ERIKSSON U, OSTMAN A. New members of the platelet-derived growth factor family of mitogens. Arch BiochemBiophys 2002; 398: 284-290. http: //dx.doi. org/10.1006/abbi.2001.2707

[8] FREDRIKSSON L, LI H, ERIKSSON U. The PDGF family: four gene products form five dimericisoforms. Cytokine \& Growth Factor Reviews 2004; 15: 197-204. http: //dx.doi. org/10.1016/j.cytogfr.2004.03.007

[9] LI X, ERIKSSON U. Novel PDGF family members: PDGF-C and PDGF-D. Cytokine Growth Factor Rev 2003; 14: 91-98. http: //dx.doi.org/10.1016/S1359-6101(02)00090-4

[10] UEHARA H, KIM SJ, KARASHIMA T, SHEPHERD DL, FAN $\mathrm{D}$, et al. Effects of blocking platelet-derived growth factor-re- 
ceptor signaling in a mouse model of experimental prostate cancer bone metastases. J Natl Cancer Inst 2003; 95: 458-470. http: //dx.doi.org/10.1093/jnci/95.6.458

[11] KUMAR A, HOU X, LEE C, LI Y, MAMINISHKIS A, et al. PDGF-DD targeting arrests pathological angiogenesis by modulating glycogen synthase kinase 3 beta (GSK3 $\beta$ ) phosphorylation. Journal of Biological Chemistry 2010; 10: 1074-1085.

[12] KODAMA M, KITADAI Y, SUMIDA T, OHNISHI M, OHARA E, et al. Expression of platelet-derived growth factor (PDGF)-B and PDGF-receptor b is associated with lymphatic metastasis in human gastric carcinoma. Cancer Science 2010; 101: 1984-1989. http: //dx.doi.org/10.1111/ j.1349-7006.2010.01639.x

[13] KONG D, LI Y, WANG Z, BANERJEE S, AHMAD A, et al. miR-200 Regulates PDGF-D-Mediated Epithelial-Mesenchymal Transition, Adhesion, and Invasion of Prostate Cancer Cells. STEM CELLS 2009; 27: 1712-1721. http: //dx.doi. org/10.1002/stem.101

[14] PIETRAS K. Increasing tumor uptake of anticancer drugs with imatinib. Semin Oncol 2004; 31: 18-23. http: //dx.doi. org/10.1053/j.seminoncol.2004.03.036

[15] BRAZIL DP, HEMMINGS BA. Ten years of proteinkinaseBsignalling: a hard Akt to follow. Cell 2001; 26: 657-664.

[16] SUZUKI S, DOBASHI Y, HATAKEYAMA Y, TAJIRI R, FUJIMURA T, et al. Clinicopathological significance of platelet-derived growth factor (PDGF)-B and vascular endothelial growth factor-A expression, PDGF receptor-b phosphorylation, and microvessel density in gastric cancer. BMC Cancer 2010; 10: 659-669. http: //dx.doi.org/10.1186/1471-2407-10$\underline{659}$

[17] LOIS C, HONG EJ, PEASE S, BROWN EJ, BALTIMORE D. Germline transmission and tissue-specific expression of transgenes delivered by lentiviralvectors. Science 2002; 295 : 868-872. http: //dx.doi.org/10.1126/science.1067081

[18] XIA X, ZHANG Y, ZIETH CR. Transgenes Delivered by Lentiviral Vector Are Suppressed in Human Embryonic Stem Cells in a Promoter-Dependent Manner. STEM CELLS AND DEVELOPMENT 2007; 16: 167-176.

[19] LEE JS, HMAMA Z, MUI A, REINER NE. Stable gene silencing in human monocytic cell lines using lentiviral-delivered small interference RNA. Silencing of the p110 alpha isoform of phosphoinositide 3-kinase reveals differential regulation of adherence induced by 1alpha, 25-dihydroxycholecalciferol and bacterial lipopolysaccharide. The Journal of Biological Chemistry 2004; 279: 9379-9388. http://dx.doi.org/10.1074/ jbc.M310638200

[20] SONG KS, LI G, KIM JS, JING K, KIM TD, et al. Proteinbound polysaccharide from Phellinuslinteus inhibits tumor growth, invasion, andangiogenesis and alters Wnt/ $\beta$-catenin in SW480human colon cancer cells. BMC Cancer 2011; 11: 307-318. http: //dx.doi.org/10.1186/1471-2407-11-307

[21] SETON-ROGRES SE, LU Y, HINES LM, KOUNDINYA M, LABAER J, et al. Cooperation of the ErbB2 receptor and transforming growth factor $\beta$ in induction of migration and invasion in mammary epithelial cells. PNAS 2004; 101 : 1257-1262. http: //dx.doi.org/10.1073/pnas.0308090100
[22] CHIGURUPATI S, KULKARNI T, THOMAS S, SHAH G. Calcitonin Stimulates Multiple Stages of Angiogenesis by Directly Acting on Endothelial Cells. Cancer Research 2005; 65: 8519-8529. http: //dx.doi.org/10.1158/0008-5472.CAN$\underline{05-0848}$

[23] KONG D, LI Y, WANG Z, BANERJEE S, SARKAR FH. Inhibition of angiogenesis and invasionby 3,3'-diindolylmethane is mediated by the nuclear factor-kappaBdownstream target genes MMP-9 and uPA that regulated bioavailability of vascular endothelial growth factor in prostate cancer. Cancer Res 2007; 67: 3310-3319. http: //dx.doi.org/10.1158/0008-5472. CAN-06-4277

[24] BARRY JJ, JIAN BJ, SUGHRUE ME, KANE AJ, MILLS SA, et al. The Next Step: Innovative Molecular Targeted Therapies for Treatment of Intracranial ChordomaPatients. Neurosurgery 2011; 68: 231-241. http://dx.doi.org/10.1227/ NEU.0b013e3181fd2ac5

[25] AMMOUN S, FLAIZ C, RISTIC N, SCHULDT J, HANEMANN CO. Dissecting and targeting the growth factor dependent and growth factor independent extracellular signal regulated kinase pathway in human schwannoma. Cancer Res 2008; 68: 5236-5245. http: //dx.doi.org/10.1158/0008-5472. CAN-07-5849

[26] LINDMARK G, SUNDBERG C, GLIMELIUS B, PAHLMAN L, RUBIN K, et al. Stromal expression of platelet-derived growth factor beta-receptor and platelet-derived growth factor B-chain in colorectal cancer. Journal of Technical Methods and Pathology 1993; 69: 682-689.

[27] MAASS T, THIERINGER FR, MANN A, LONGERICH T, SCHIRMACHER P, et al. Liver specific overexpression of platelet-derived growth factor-B accelerates liver cancer development in chemically induced liver carcinogenesis. International Journal of Cancer 2011; 128: 1259-1268. http: //dx.doi.org/10.1002/ijc.25469

[28] WANG Y, JI M, WANG W, MIAO Z, HOU P, et al. Association of the T1799A BRAF mutation with tumor extrathyroidal invasion, higher peripheral platelet counts, and over-expression of platelet-derived growth factor-B in papillary thyroid cancer. Endocrine-Related Cancer 2008; 15: 183-190. http: //dx.doi. org/10.1677/ERC-07-0182

[29] MAZZOCCA A, FRANSVEA E, DITURI F, LUPO L, ANTONACI S, et al. Down-regulation of connective tissue growth factor by inhibition of transforming growth factor $\beta$ blocks the tumor-stroma cross-talk and tumor progression in hepatocellular carcinoma. Hepatology 2010; 51: 523-534. http: //dx.doi.org/10.1002/hep.23285

[30] FOLKMAN J. Antiangiogenesis in cancer therapy-endostatin and its mechanisms of action. Experimental Cell Research 2006; 312: 594-607. http: //dx.doi.org/10.1016/ j.yexcr.2005.11.015

[31] MANNING BD, CANTLEY LC. AKT/PKB Signaling: Navigating Downstream. Cell 2007; 129: 1261-1274. http://dx.doi. org/10.1016/j.cell.2007.06.009

[32] WANG Z, LI Y, BANERJEE S, KONG D, AHMAD A, et al. Down-regulation of Notch-1 and Jagged-1 inhibits prostate cancer cell growth, migration and invasion, and induces apoptosis via inactivation of Akt, mTOR, and NF- $\kappa$ B signal- 
ing pathways. Journal of Cellular Biochemistry 2010; 109: 726-736.

[33] METALLI D, LOVAT F, F TRIPODI, GENUA M, XU SQ, et al. The Insulin-Like Growth Factor Receptor I Promotes Motility and Invasion of Bladder Cancer Cells through Aktand Mitogen-Activated Protein Kinase-Dependent Activation of Paxillin. The American Journal of Pathology 2009; 176: 2997-3006. http: //dx.doi.org/10.2353/ajpath.2010.090904

[34] CHIN YR, TOKER A. Function of Akt/PKB signaling to cell motility, invasion and the tumor stroma in cancer. Cellular Signalling 2009; 21: 470-476. http: //dx.doi.org/10.1016/ j.cellsig.2008.11.015 